\title{
Facultative parthenogenesis in the burrowing mayfly, Ephoron eophilum (Ephemeroptera: Polymitarcyidae) with an extremely short alate stage
}

\author{
Kazuki SEKINÉ ${ }^{1,2}$, KoJi TOJO ${ }^{3,4}$ and YeOn JAe BAE ${ }^{1,2,5, *}$ \\ ${ }^{1}$ BK21 Plus Eco-Leader Education Center, Korea University, Seoul 136-713, Korea; e-mail: ksekine1108@korea.ac.kr \\ ${ }^{2}$ Korean Entomological Institute, College of Life Sciences and Biotechnology, Korea University, Seoul 136-713, Korea \\ ${ }^{3}$ Department of Biology, Faculty of Science, Shinshu University, Asahi 3-1-1, Matsumoto, Nagano 390-8621, Japan; \\ e-mail: ktojo@shinshu-u.ac.jp \\ ${ }^{4}$ Institute of Mountain Science, Shinshu University, Asahi 3-1-1, Matsumoto, Nagano 390-8621, Japan \\ ${ }^{5}$ Division of Environmental Science and Ecological Engineering, College of Life Sciences and Biotechnology, Korea University, \\ Seoul 136-713, Korea; e-mail: yjbae@korea.ac.kr
}

Key words. Ephemeroptera, Ephoron eophilum, facultative parthenogenesis, diploid thelytoky, Hardy-Weinberg equilibrium, exon-primed intron-crossing (EPIC) markers, short adult stage

\begin{abstract}
Facultative parthenogenesis is important for mayflies with short alate stages because females are able to reproduce without mating. We studied facultative parthenogenesis in Ephoron eophilum, a mayfly with an extremely short alate stage. We examined the survival rates of embryos from unfertilized eggs, in addition to investigating the number of chromosomes in parthenogenetic offspring and the mode of inheritance by nuclear genetic analyses using Exon-Primed Intron-Crossing markers. The survival rate of thelytokous embryos was $0-70.2 \%(16.7 \pm 26.7 \%$, mean \pm S.D. $)$. Sixteen chromosomes were present throughout most of the mitotic metaphase in parthenogenetic offspring, which was similar to the number recorded in diploid females. All parthenogenetic offspring were homozygous in nuclear genetic analyses, despite the presence of heterozygous mothers. These results indicate that E. eophilum has the ability to reproduce via facultative parthenogenesis, producing mostly diploid thelytokous offspring. The restoration of ploidy level occurs by automixis via terminal fusion or gamete duplication, and causes rapid reduction of heterozygosity. However, despite this, significant deviation from Hardy-Weinberg equilibrium (HWE) was not observed in the studied populations. This is because facultative parthenogenesis in these circumstances normally has little influence on population genetic structuring, even though parthenogenetic embryos exhibit a high survival rate. The lack of influence of parthenogenesis on the population structure of the natural population strongly suggests that parthenogenesis rarely occurs under natural circumstances.
\end{abstract}

\section{INTRODUCTION}

Cytological thelytokous parthenogenesis (i.e., when females are produced from unfertilized eggs) occurs as two main forms (Suomalainen et al., 1987): apomictic (or ameiotic) and automictic (or meiotic). In apomictic parthenogenesis, alleles do not undergo recombination; thus, offspring are "true clones" of the mother. In automictic parthenogenesis, the first stages of meiosis are similar to those in sexual reproduction, but fusion occurs between two nuclei originating from the same individual. Gene recombination may occur in automictic parthenogenesis. Therefore, the two types of parthenogenesis give rise to different patterns of heredity (Templeton, 1982; Pearcy et al., 2006).

Obligatory parthenogenesis is rare; it has been reported in only $0.1 \%$ of the hexapod species examined (Normark, 2014). However, obligatory parthenogenesis has been reported occurring at a relatively high frequency in Ephemeroptera $(0.4 \%$ of described species), although is lower in other aquatic insects, i.e., Odonata $(0.02 \%$; Cordero et al., 2005), Plecoptera (0\%), and Trichoptera (0.05\%; Corbet, 1966). In contrast, facultative parthenogenesis has the potential to cause the evolution of obligatory parthenogenesis
(Simon et al., 2003), and has been observed in sexual insect species, i.e., Odonata (Kato et al., 1997; Watanabe et al., 1999), Plecoptera (Harper, 1973; Fochetti \& de Figueroa, 2008), Trichoptera (Salokannnel et al., 2010; Malicky \& Pauls, 2012), and especially Ephemeroptera (e.g., Funk et al., 2010; Sekiné \& Tojo, 2010a). In this context, it is possibly that the short alate stage of mayflies is closely related to parthenogenetic reproduction and could be an adaptive trait for females in the population that cannot mate due to the limited period of this stage.

The type of parthenogenesis is mainly thelytoky, whereby only female offspring are produced, although deuterotoky, producing both female and male offspring, occurs in a few cases. A previous study that analyzed the allozymes of seven mayfly species reported that facultative parthenogenesis generates female offspring and a few males via automixis and causes a decrease of heterozygosity (Funk et al., 2010).

The bisexual polymitarcyid burrowing mayfly, Ephoron eophilum Ishiwata, (Ephemeroptera: Polymitarcyidae) has a distribution limited to the Kanto Plain in Japan (Ishiwata, 1996; Sekiné et al., 2013b). Nymphs burrow U-shaped

\footnotetext{
* Corresponding author.
} 
cavities in the clay of riverbeds and feed on particles of organic matter or detritus suspended in the water (Ishiwata, 1996; Aoyagi et al., 1998). The species has an extremely short alate stage (male subimago and imago and female subimago), lasting for a maximum of two hours. Females do not molt to the final imago stage, but lay eggs as subimagos.

Ephoron eophilum is phylogenetically closely related to E. shigae (Takahashi) (Ishiwata, 1996; Sekiné et al., 2013a), a geographically parthenogenetic species with both unisexual and bisexual populations that is widely distributed throughout Japan, Korea, and Russian Far East (Watanabe \& Ishiwata, 1997; Tojo et al., 2006). Although obligatory parthenogenesis is observed within unisexual populations of E. shigae, facultative parthenogenesis is also observed in the bisexual populations of this species (Sekiné \& Tojo, $2010 \mathrm{a}, \mathrm{b})$. These studies showed that the survival rates of diploid thelytokous embryos were noticeably lower in the unfertilized eggs of E. shigae under facultative parthenogenesis (mean 14.1\%) than obligatory parthenogenesis $(89.2 \%)$. A previous study involving histochemical analyses clarified that obligatory parthenogenesis in this species is automictic, with terminal fusion occurring through the mature egg nucleus fusing with its sister second polar body nucleus to form a single embryonic nucleus (Sekiné \& Tojo, 2010b).

The main objective of the present study was to evaluate the parthenogenetic capacity of E. eophilum, and the cytological mode of parthenogenesis (i.e., ploidy, sexuality, and automixis or apomixis). In the case of diploid thelytoky, we attempted to elucidate using exon-primed intron-crossing (EPIC) markers for nuclear genes whether apomixis produces only asexual lineages (clones), whilst automixis generates both homo- and heterozygotic offspring. Currently, unlike microsatellite markers, EPIC markers are relatively easily to develop and hence are the most widely used nuclear sequence markers for phylogeographic studies (Thomson et al., 2010). Lastly, we examined the bias of genetic structure expected following parthenogenetic reproduction on the characteristic patterns of heredity, i.e. to assess whether there was significant deviation from HWE expectations in terms of homo-and heterozygote numbers within the natural populations sampled.

\section{MATERIAL AND METHODS}

\section{Embryonic development}

We collected about 30 female last instar nymphs of E. eophilum from the Kinu-gawa River of the Tone-gawa River Basin on July 12, 2009 (Joso, Ibaraki Prefecture: 360 $07^{\prime} 03^{\prime \prime} \mathrm{N}, 139^{\circ} 58^{\prime} 03^{\prime \prime} \mathrm{E}$ ). Following the methods of Sekiné \& Tojo (2010a) for collecting unfertilized eggs and estimating their survival rates of thelytokous embryos, we separately reared 30 nymphs in the laboratory of which only one grew to the adult stage. Thereafter, unfertilized eggs were collected from a single reared virgin female subimago (Mother -a). In addition, we dissected six final instar female nymphs (Mothers -b to - $\mathrm{g}$ ) and obtained their unfertilized eggs. As a control, fertilized eggs were obtained from ten mated female subimagos (Mothers -A to -L) from the population collected from the Sakura-gawa River on August 20, 2008 (Tsuchiura, Ibaraki
Prefecture: $36^{\circ} 05^{\prime} 27^{\prime \prime} \mathrm{N}, 140^{\circ} 10^{\prime} 26^{\prime \prime} \mathrm{E}$ ) in the Tone-gawa River Basin.

The fertilized and unfertilized eggs were separately incubated in batches at $20 \pm 0.5^{\circ} \mathrm{C}$. During the embryogenesis of this mayfly species, diapause occurs at the last embryonic stage (Aoyagi et al., 1998; Nakamura \& Endo, 2001), which is equivalent to stage 13 in embryos of the ephemerid burrowing mayfly, Ephemera japonica McLachlan (Ephemeroptera: Ephemeridae) (cf. Tojo \& Machida, 1997). After about six months of incubation, embryo survival rates were measured under a microscope (SMZ1500, Nikon, Tokyo, Japan) for each egg batch of fertilized and unfertilized eggs.

After the nymphs began hatching, the number of chromosomes in each offspring were counted. The chromosome samples were prepared using Giemsa staining (Sekiné \& Tojo, 2010a,b) and photographed under a light microscope (80i, Nikon, Tokyo, Japan) at $1000 \times$ magnification.

\section{Genetic analyses}

In addition to samples used for observation of embryonic development, we collected female subimagos and male imagos of E. eophilum for genetic analysis from Kinu-gawa $(\mathrm{N}=15)$ and Sakura-gawa Rivers $(\mathrm{N}=13)$ of the Tone-gawa River Basin on August 25, 2007 and August 20, 2006, respectively. Specimens were fixed in $95 \%$ ethanol and included maternal subimagos $(\mathrm{N}=$ 11), last instar nymphs $(\mathrm{N}=6)$, and first instar nymphs $(\mathrm{N}=31)$ which hatched from unfertilized eggs. Total genomic DNA was extracted from the whole body or tissues of the ethanol-preserved specimens and purified using a standard cetyltrimethylammonium bromide (CTAB) protocol (Wang \& Wang, 2012). Total RNA was extracted from the last instar nymphs using an RNeasy Mini kit (Qiagen, Venlo, Netherlands). The RACE-ready cDNA libraries were prepared using a SMART RACE cDNA Amplification Kit (Clontech, Mountain View, US) and the total RNA.

We designed the EPIC primers for the nuclear elongation factor-1 alpha $1(E F-1 \alpha)$ and boule genes conserved among animals. Primers of $E F-1 \alpha$ were designed based on sequences of Hexagenia limbata (Serville) (Accession No. AY305469) and Ephemerella inconstans Traver (GQ886698) in Ephemeroptera (Ephemeridae and Ephemerellidae, respectively) and Drosophila melanogaster Meigen (X06870) in Diptera (Drosophildae). Degenerate primer PCR to obtain partial cDNA of boule gene orthologues was performed using primers (5'-GTGCCGAAYCGCGTGTTTGTGG-3' and 5'-TCTCRAASGTGATGAARCCGTARCC-3') corresponding to highly conserved regions of respective genes of the mayfly Ephemera danica Müller (Ephemeridae) (GAUK01089074), the sawfly Athalia rosae (L.) (Hymenoptera: Tenthredinidae) (AB719982) the red flour beetle Tribolium castaneum Herbst (Coleoptera: Tenebrionidae) (EFA05679), and the fruit fly D. melanogaster (AAF50316), as in previous studies (Sekiné et al., 2015). Subsequently, the adjacent 5' and 3' regions identified by using the RACE-ready cDNA libraries and genespecific primers (5'-GCGGACTTTCTGCAGACACAACAG-3' and 5'-TTTGGAGACTCCTGCGCGATCAC-3').

These were partially amplified by polymerase chain reaction (PCR) using the following primer sets: $E F-1 \alpha$ : 5'-CCTGGGTGTTGGACAAGCTCAAG-3' and 5'-AAGACGCAGGGGCTTCTCTG-3'; boule: 5'-GTGCCGAAYCGCGTGTTTGTGG-3' and 5'-GGTAAGAGTAATTCTGCGGAGTG-3'. PCR products were then purified using ExoSap-IT (GE Healthcare, Buckinghamshire, UK), and the purified DNA fragments sequenced directly on an automated sequencer (Applied Biosystems, ABI 3130xl DNA Analyzer, Waltham, USA) using an automated method involving BigDye Terminator v1.1 or 3.1 Cycle Sequencing Kits (Applied Biosystems). 

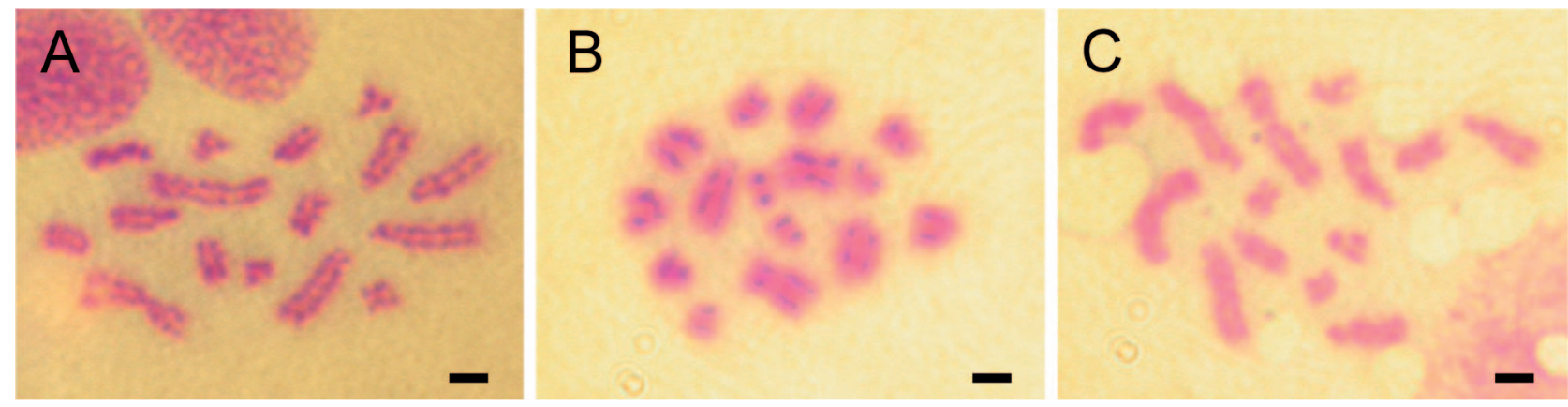

Fig. 1. Mitotic metaphase chromosomes prepared from parthenogenetically developed nymphs. Chromosomes of $2 \mathrm{n}=16$ (A), 15 (B), and 14 (C). Scale bars $=1 \mu \mathrm{m}$.

All sequences were aligned and checked for double peaks using CLC Workbench software (CLC bio, Aarhus, Denmark), the results being cross-checked using the Clustal W (Larkin et al., 2007) algorithm, implemented in MEGA5.10 (Tamura et al., 2011). EF-1 $\alpha$ and boule sequences were submitted to the DNA data Bank of Japan (DDBJ database) with accession numbers LC013981-LC014119. The PHASE algorithm (Stephens et al., 2001; Stephens \& Donnelly, 2003), as implemented in DnaSP v5 (Librado \& Rozas, 2009), was used to reconstruct putative alleles of the nuclear $E F-1 \alpha$ and boule genes, and to calculate statistical parsimony trees (network tree) using TCS, version 1.21 (Clement et al., 2000).

The exact tests of HWE (Wigginton et al., 2005) were used to test $E F-1 \alpha$ and boule genes for single nucleotide polymorphisms (SNPs) in parthenogenetic progenies reared in the laboratory and individuals from the Kinu-gawa and Sakura-gawa populations.

\section{RESULTS}

The overwhelming majority of embryos from all 10 fertilized egg batches developed to the final stage $(94.9 \pm$ 6.7\%, mean $\pm \mathrm{SD}$; maximum: $99.7 \%$, minimum: $78.1 \%$; Table 1). In contrast, eggs from only four out of the seven unfertilized batches developed to the final stage (16.7 \pm $26.7 \%$, mean $\pm \mathrm{SD}$; maximum: $70.2 \%$; minimum: $0 \%$ ). Most nymphs hatched from unfertilized eggs had $16 \mathrm{mi}-$ totic metaphase chromosomes (15 individuals out of 19; Fig. 1A), but four individuals had different chromosome numbers (i.e., 14 and 15 chromosomes were observed in 1 and 3 individuals, respectively; Fig. 1B, C).

In the Sakura-gawa and Kinu-gawa populations (Fig. 2A, B), and using the PHASE algorithm, it was estimated

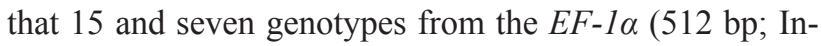
tron-I 58, Exon-I 168, Intron-II 190, and Exon-II 96) and boule (694 bp; Exon-I 205, Intron-I 283, and Exon-II 206) sequences with introns, respectively, occured within the 68 individuals tested, excluding parthenogenetic offspring. However, the genotype IV and genotype I predominated in $E F-1 \alpha$ and boule, respectively, thirteen and five substitutions were observed, with 55 and 53 out of the 68 individuals being heterozygous at one or more positions in $E F-1 \alpha$ and boule, respectively. In addition, no genetic differentiation between the Sakura-gawa and Kinu-gawa populations was found.

TABLE 1. Survival rate of embryos from fertilized or unfertilized eggs of Ephoron eophilum.

\begin{tabular}{|c|c|c|c|c|}
\hline & $\begin{array}{l}\text { Mother } \\
\text { individual }\end{array}$ & $\begin{array}{l}\text { Number of eggs } \\
\text { examined }\end{array}$ & $\begin{array}{l}\text { Number of embryos developing } \\
\text { to the final embryonic stage }\end{array}$ & $\begin{array}{l}\text { Rate of embryos developing } \\
\text { to the final embryonic stage }\end{array}$ \\
\hline \multirow[t]{10}{*}{ Fertilized eggs } & $\mathrm{A}$ & 725 & 686 & $94.6 \%$ \\
\hline & B & 105 & 82 & $78.1 \%$ \\
\hline & $\mathrm{C}$ & 270 & 264 & $97.8 \%$ \\
\hline & $\mathrm{D}$ & 915 & 910 & $99.5 \%$ \\
\hline & G & 33 & 30 & $90.9 \%$ \\
\hline & $\mathrm{H}$ & 549 & 542 & $98.7 \%$ \\
\hline & I & 866 & 857 & $99.0 \%$ \\
\hline & $\mathrm{J}$ & 831 & 762 & $91.7 \%$ \\
\hline & K & 385 & 382 & $99.2 \%$ \\
\hline & $\mathrm{L}$ & 287 & 286 & $99.7 \%$ \\
\hline \multirow[t]{7}{*}{ Unfertilized eggs } & $\mathrm{a}$ & 409 & 142 & $34.7 \%$ \\
\hline & $b^{*}$ & 1511 & 1061 & $70.2 \%$ \\
\hline & $\mathrm{c}^{*}$ & 626 & 66 & $10.5 \%$ \\
\hline & $d^{*}$ & 1437 & 19 & $1.3 \%$ \\
\hline & $\mathrm{e}^{*}$ & 1865 & 0 & $0.0 \%$ \\
\hline & $\mathrm{f}^{*}$ & 1683 & 0 & $0.0 \%$ \\
\hline & $g^{*}$ & 776 & 0 & $0.0 \%$ \\
\hline
\end{tabular}

*Unfertilized eggs obtained from final instar female nymphs by dissection. 


\section{(A) $E F-1 a$}

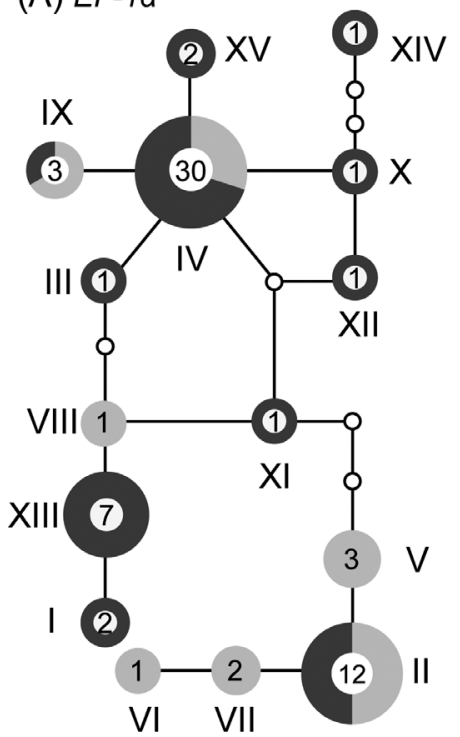

(B) boule

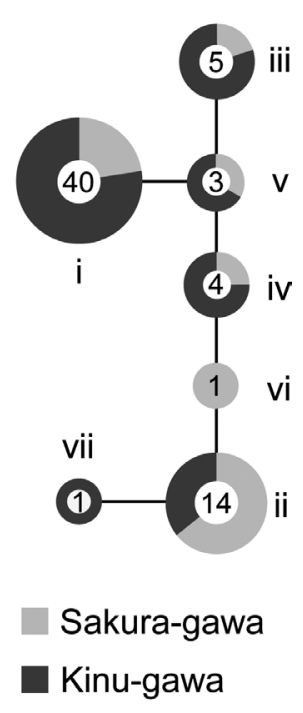

Fig. 2. Statistical parsimony network for the $E F-1 \alpha$ (A) and boule (B) of E. eophilum in the Sakura-gawa and Kinu-gawa River populations. Solid lines connect genotypes with a single step (missing intermediates are shown by an open circle). The size of the circle and Arabic numerals indicates the number of genotypes, whilst the division within the circle shows the proportion of two populations in which the genotype was detected. Roman numerals represent the genotype names presented in Table 2 .

Four and two genotypes for $E F-1 \alpha$ and boule, respectively, were identified in offspring parthenogenetically generated from mothers -a, -b, and -c (Table 2). Mothers -a and -d were homozygous, while -b, -c, -e, -f, and -g were heterozygous at the 7 and 5 sequence positions in $E F-1 \alpha$ and boule, respectively. All parthenogenetic offspring analyzed were homozygous in both genes independent of whether the mother was homo- or heterozygous.

In the exact tests of HWE for the SNPs of $E F-1 \alpha$ and boule genes, significant deviations from expectations were observed in parthenogenetic progenies for almost all SNPs $(\mathrm{N}=33)$, but not in the Kinu-gawa and Sakura-gawa populations $(\mathrm{N}=33$, Table 3$)$. Although there was no observed significant deviation from HWE for position 140 in the boule sequences, all parthenogenetic progenies were homozygous for guanine.

\section{DISCUSSION}

This study confirmed that E. eophilum is capable of facultative parthenogenesis. This species mostly has a diploid chromosome number of $2 \mathrm{n}=15$ ( $\overbrace{}^{\Uparrow})$ or $2 \mathrm{n}=16$ (q), and rarely variant chromosome numbers (Sekiné et al., 2013a). Our results indicate that when unfertilized E. eophilum eggs undergo parthenogenesis, they usually generate diploid female offspring $(2 \mathrm{n}=16)$, i.e., diploid thelytoky. In addition, some parthenogenetic offspring had different

TABLE 2. Partial sequences of EF-1 $\alpha$ and boule genes in offspring developed from unfertilized eggs and mothers.

\begin{tabular}{|c|c|c|c|c|c|c|c|c|c|}
\hline \multicolumn{10}{|c|}{$E F-1 \alpha(512$ bp $)$} \\
\hline & \multirow{2}{*}{$\begin{array}{c}\text { Number } \\
\text { of individuals }\end{array}$} & \multicolumn{7}{|c|}{ Sequence position } & \multirow{2}{*}{ Genotype* } \\
\hline & & 4 & 10 & 175 & 260 & 265 & 335 & 412 & \\
\hline Mother-a & 1 & $\mathrm{~A}$ & $\mathrm{G}$ & $\mathrm{A}$ & $\mathrm{C}$ & $\mathrm{G}$ & $\mathrm{C}$ & $\mathrm{C}$ & $\mathrm{I} / \mathrm{I}$ \\
\hline offspring & 10 & $\mathrm{~A}$ & G & A & $\mathrm{C}$ & G & $\mathrm{C}$ & $\mathrm{C}$ & $\mathrm{I} / \mathrm{I}$ \\
\hline Mother-b & 1 & $\mathrm{~A} / \mathrm{G}$ & $\mathrm{A} / \mathrm{G}$ & $\mathrm{A} / \mathrm{G}$ & $\mathrm{C} / \mathrm{T}$ & $\mathrm{A} / \mathrm{G}$ & $\mathrm{C} / \mathrm{G}$ & $\mathrm{C} / \mathrm{T}$ & II / III \\
\hline offspring & 7 & G & G & G & $\mathrm{C}$ & G & $\mathrm{C}$ & $\mathrm{C}$ & II / II \\
\hline offspring & 5 & A & A & A & $\mathrm{T}$ & A & G & $\mathrm{T}$ & III / III \\
\hline Mother-c & 1 & $\mathrm{~A} / \mathrm{G}$ & $\mathrm{A} / \mathrm{G}$ & $\mathrm{A} / \mathrm{G}$ & $\mathrm{C} / \mathrm{T}$ & $\mathrm{A} / \mathrm{G}$ & $\mathrm{G}$ & $\mathrm{C} / \mathrm{T}$ & III / IV \\
\hline offspring & 7 & G & $\mathrm{G}$ & G & $\mathrm{C}$ & $\mathrm{G}$ & $\mathrm{G}$ & $\mathrm{C}$ & IV / IV \\
\hline offspring & 2 & A & A & A & $\mathrm{T}$ & A & G & $\mathrm{T}$ & III / III \\
\hline Mother-d & 1 & G & $\mathrm{G}$ & G & $\mathrm{C}$ & G & $\mathrm{G}$ & $\mathrm{C}$ & IV / IV \\
\hline Mother-e & 1 & $\mathrm{~A} / \mathrm{G}$ & $\mathrm{A} / \mathrm{G}$ & $\mathrm{A} / \mathrm{G}$ & $\mathrm{C} / \mathrm{T}$ & $\mathrm{A} / \mathrm{G}$ & G & $\mathrm{C} / \mathrm{T}$ & III / IV \\
\hline Mother-f & 1 & $\mathrm{~A} / \mathrm{G}$ & $\mathrm{A} / \mathrm{G}$ & $\mathrm{A} / \mathrm{G}$ & $\mathrm{C} / \mathrm{T}$ & $\mathrm{A} / \mathrm{G}$ & G & $\mathrm{C} / \mathrm{T}$ & III / IV \\
\hline Mother-g & 1 & $\mathrm{~A} / \mathrm{G}$ & $\mathrm{A} / \mathrm{G}$ & $\mathrm{A} / \mathrm{G}$ & $\mathrm{C} / \mathrm{T}$ & $\mathrm{A} / \mathrm{G}$ & G & $\mathrm{C} / \mathrm{T}$ & III / IV \\
\hline \multicolumn{10}{|c|}{ boule (694 bp) } \\
\hline & \multirow{2}{*}{$\begin{array}{c}\text { Number } \\
\text { of individuals }\end{array}$} & \multicolumn{5}{|c|}{ Sequence position } & \multirow{2}{*}{ Genotype* } & & \\
\hline & & 112 & 300 & 306 & 437 & 689 & & & \\
\hline Mother-a & 1 & $\mathrm{G}$ & A & $\mathrm{C}$ & $\mathrm{A}$ & $\mathrm{T}$ & $\mathrm{i} / \mathrm{i}$ & & \\
\hline offspring & 10 & G & A & $\mathrm{C}$ & A & $\mathrm{T}$ & $\mathrm{i} / \mathrm{i}$ & & \\
\hline Mother-b & 1 & $\mathrm{G}$ & $\mathrm{A} / \mathrm{C}$ & $\mathrm{C} / \mathrm{T}$ & $\mathrm{A} / \mathrm{T}$ & $\mathrm{C} / \mathrm{T}$ & i / ii & & \\
\hline offspring & 7 & $\mathrm{G}$ & A & $\mathrm{C}$ & A & $\mathrm{T}$ & $\mathrm{i} / \mathrm{i}$ & & \\
\hline offspring & 5 & G & C & $\mathrm{T}$ & $\mathrm{T}$ & C & ii / ii & & \\
\hline Mother-c & 1 & $\mathrm{G}$ & $\mathrm{A} / \mathrm{C}$ & $\mathrm{C} / \mathrm{T}$ & $\mathrm{A} / \mathrm{T}$ & $\mathrm{C} / \mathrm{T}$ & i / ii & & \\
\hline offspring & 7 & G & A & $\mathrm{C}$ & A & $\mathrm{T}$ & $\mathrm{i} / \mathrm{i}$ & & \\
\hline offspring & 2 & G & $\mathrm{C}$ & $\mathrm{T}$ & $\mathrm{T}$ & $\mathrm{C}$ & ii / ii & & \\
\hline Mother-d & 1 & G & A & $\mathrm{C}$ & A & $\mathrm{T}$ & $\mathrm{i} / \mathrm{i}$ & & \\
\hline Mother-e & 1 & $\mathrm{G} / \mathrm{T}$ & $\mathrm{C}$ & $\mathrm{C} / \mathrm{T}$ & $\mathrm{A} / \mathrm{T}$ & $\mathrm{C} / \mathrm{T}$ & ii / iii & & \\
\hline Mother-f & 1 & G & $\mathrm{A} / \mathrm{C}$ & $\mathrm{C} / \mathrm{T}$ & $\mathrm{A} / \mathrm{T}$ & $\mathrm{C} / \mathrm{T}$ & i / ii & & \\
\hline Mother-g & 1 & G & $\mathrm{A} / \mathrm{C}$ & $\mathrm{C} / \mathrm{T}$ & $\mathrm{A} / \mathrm{T}$ & $\mathrm{C} / \mathrm{T}$ & i / ii & & \\
\hline
\end{tabular}

* Genotype names are reffered in Fig. 2. 
TABLE 3. The exact tests of Hardy-Weinberg equilibrium for SNPs of EF-1 $\alpha$ and boule genes in individuals in the Kinu-gawa and Sakura-gawa populations and in parthenogenetic progenies.

\begin{tabular}{|c|c|c|c|c|c|c|c|c|c|}
\hline \multirow{2}{*}{$\begin{array}{l}\text { Sequence } \\
\text { position }\end{array}$} & \multirow{2}{*}{ Nucleotide } & \multicolumn{4}{|c|}{ Kinu-gawa and Sakura-gawa populations } & \multicolumn{4}{|c|}{ Parthenogenetic progenies } \\
\hline & & HETERO & HOMO 1 & HOMO 2 & $P$-value & HETERO & HOMO 1 & HOMO 2 & $P$-value \\
\hline \multicolumn{10}{|c|}{$E F-1 \alpha(512 b p)$} \\
\hline 4 & $\mathrm{~A} / \mathrm{G}$ & 17 & 6 & 11 & 1.00 & 0 & 18 & 14 & $<0.001$ \\
\hline 10 & $\mathrm{~A} / \mathrm{G}$ & 11 & 3 & 20 & 0.39 & 0 & 7 & 25 & $<0.001$ \\
\hline 175 & $\mathrm{~A} / \mathrm{G}$ & 16 & 7 & 11 & 0.74 & 0 & 18 & 14 & $<0.001$ \\
\hline 260 & $\mathrm{C} / \mathrm{T}$ & 12 & 19 & 3 & 0.66 & 0 & 25 & 7 & $<0.001$ \\
\hline 265 & $\mathrm{~A} / \mathrm{G}$ & 12 & 3 & 19 & 0.66 & 0 & 7 & 25 & $<0.001$ \\
\hline 335 & $\mathrm{C} / \mathrm{G}$ & 7 & 1 & 26 & 0.46 & 0 & 18 & 14 & $<0.001$ \\
\hline 412 & $\mathrm{C} / \mathrm{T}$ & 8 & 23 & 3 & 0.11 & 0 & 25 & 7 & $<0.001$ \\
\hline \multicolumn{10}{|c|}{ boule (694 bp) } \\
\hline 112 & $\mathrm{G} / \mathrm{T}$ & 5 & 29 & 0 & 1.00 & 0 & 32 & 0 & 1.000 \\
\hline 300 & $\mathrm{~A} / \mathrm{C}$ & 13 & 14 & 7 & 0.28 & 0 & 25 & 7 & $<0.001$ \\
\hline 306 & $\mathrm{C} / \mathrm{T}$ & 11 & 21 & 2 & 0.64 & 0 & 25 & 7 & $<0.001$ \\
\hline 437 & $\mathrm{~A} / \mathrm{T}$ & 10 & 21 & 3 & 0.34 & 0 & 25 & 7 & $<0.001$ \\
\hline 689 & $\mathrm{C} / \mathrm{T}$ & 12 & 4 & 18 & 0.41 & 0 & 7 & 25 & $<0.001$ \\
\hline
\end{tabular}

HETERO, HOMO 1, and HOMO 2 indicate individual numbers of heterozygosity, homozygosity (left nucleotide in Nucleotide column), and homozygosity (right nucleotide), respectively.

chromosome numbers $(2 \mathrm{n}=14$ and 15$)$. Normal development requires a diploid complement of chromosomes as shown in other insects (Corley et al., 1999). However, abnormal (i.e. malformed) phenotypes were not observed in the 1st instar nymphs of $2 n=14$ and 15 forms of the insect (data not shown), although post-embryological development was not followed by us. In E. eophilum, individuals with chromosome number $2 \mathrm{n}=15(\mathrm{X} 0)$ and $16(\mathrm{XX})$ are male and female, respectively, (Sekiné et al., 2013a). In species with XX: X0 sex determination (i.e. males and females have 1 and $2 \mathrm{X}$ chromosomes, respectively), parthenogenetically derived males may develop as a consequence of accidental sex chromosome loss due to non-disjunction (cf. van der Kooi \& Schwander, 2014). Indeed, it has been proposed that deuterotoky, which generates both parthenogenetic males and females from unfertilized eggs, occurs in some mayflies (Huff \& McCafferty, 1974; Mingo, 1978; Funk et al., 2010). Although it is unclear whether E. eophilum parthenogenetic nymphs with chromosome number $2 \mathrm{n}=15$ in this study lost a sex chromosome, deuterotoky could occur in E. eophilum. Alternatively, different chromosome numbers may arise because of the presence of $\mathrm{B}$ chromosomes, as suggested by Sekiné et al. (2013a).

In the nuclear analyses of $E F-1 \alpha$ and boule genes as EPIC markers, various genotypes were observed, although there was a weak bias in terms of genotype distribution. In addition, there was no evidence of population genetic differentiation due to a restriction of gene flow between the Sakura-gawa and Kinu-gawa populations. Hence, our observation that all parthenogenetic offspring were homozygous despite having heterozygous mothers, is a result obtained without the application of time-consuming histochemical methods and development of microsatellite markers. This finding indicates that the restoration of the ploidy level occurs via automixis during meiosis. Obligatory parthenogenesis in E. shigae is also automictic, with terminal fusion occurring through the mature egg nucleus fusing with its sister second polar body nucleus to form a single embryonic nucleus (Sekiné \& Tojo, 2010b). Central fusion and gamete duplication are also known as a consequence of other automictic modes (Suomalainen et al., 1987). In central fusion, diploidy is recovered either by the fusion of the egg nucleus with one of the non-sister nuclei derived from the first polar body, or by the fusion of two of the non-sister polar bodies. In gamete duplication, diploidy in homozygous condition is recovered only after the first cleavage following the fusion of two blastomere nuclei. Terminal fusion and gamete duplication rapidly cause heterozygosity to decrease in automixis, even though the rates of transition to homozygosity of heterozygous loci differ according to the distance from the centromere. In the case of terminal fusion, the expected rates are 1.00 close to the centromere (no recombination) and 0.33 far from the centromere (substantial recombination) (Templeton, 1982; Pearcy et al., 2006). In this study, the facultative parthenogenesis of E. eophilum reduced heterozygosity so rapidly that the rates of transition from heterozygosities to homozygosities were 1.00 at both the EF-1 $\alpha$ and boule loci. Thus, it is possible that in E. eophilum either terminal fusion (in which the $E F-1 \alpha$ and boule loci are close to the centromere) or gamete duplication cause the restoration of the ploidy level during diploid thelytoky.

A previous study indicated that facultative parthenogenesis is an important trait that allows mayflies with a short adult stage to reproduce and form new populations, even if males are not available for mating (Funk et al., 2010). Most Ephoron adults have an extremely short lifespan (maximum $\sim 2 \mathrm{~h}$ ), with females of E. eophilum and E. shigae ovipositing with minimal stimulus (e.g. moisture or touch) even without mating (Sekiné \& Tojo, 2010a). E. shigae in Japan and E. album (Say) in North America also have facultatively parthenogenetic ability; $0.3-34.7 \%$ (Sekiné 
\& Tojo, 2010a) and 8-10\% (Britt, 1962), respectively, of the unfertilized eggs developed to the final stage. Like Ephoron, Palingenia longicauda Olivier (Ephemeroptera: Palingeniidae) in Europe also has an extremely short adult stage ( $<2$ h: Russev, 1987) and has about 50\% parthenogenetic ability (Landolt et al., 1997). In comparison, the facultative parthenogenetic ability in the Japanese mayflies in the sister family Ephemeridae is relatively low, as shown in Ephemera strigata Eaton (mean 0.9\%), Ephemera japonica (1.1\%), and Ephemera orientalis McLachlan $(0.6 \%)$, whose adult stages last a few days (Sekiné \& Tojo, 2010a). Therefore, facultative parthenogenetic ability may be related to adult life span as well as mating and oviposition behaviour.

Even so, there was no evidence of deviation from HWE in the Kinu-gawa and Sakura-gawa populations, although in theory, parthenogenesis rapidly reduces the level of heterozygosity. From this it may be concluded that facultative parthenogenesis in these circumstances normally has little influence on population genetic structuring. Hence, the apparent lack of influence of parthenogenesis on the population structure of the natural population of E. eophilum strongly suggests that parthenogenesis rarely occurs in the wild, where both male and female individuals are abundant. This result is clearly at variance with previous views arguing that facultative parthenogenesis is important for mayflies that have a short reproductive alate stage, during which time females may fail to find males to mate with in the extremely brief "window of opportunity" available to them (Funk et al., 2010). In light of this, the reproductive/genetic characteristics of E. eophilum - in theory at least - doubtless contribute to maintaining small populations in harsh environments or populations that have been disrupted by ecological disturbance.

ACKNOWLEDGEMENTS. We thank M. Hatakeyama of the National Institute of Agrobiological Sciences for their very helpful comments, H.D. Loxdale for his editorial improvements to the manuscript, and T. Suzuki, R. Saito, J.I. Jo, and M. Takenaka of Shinshu University for preparation of samples. This work was supported by the BK21 Plus program in 2014 (Project No. 21A20130012270) funded by National Research Foundation of Korea (NRF).

\section{REFERENCES}

Aoyagi I., Tetsuka M. \& NaKamura K. 1998: Morphology of early instar larvae and life history of Ephoron eophilum (Ephemeroptera: Polymitarcyidae). - Jpn. J. Limnol. 59: 185-198 [in Japanese with English abstr. and captions].

BritT N.W. 1962: Biology of two species of Lake Erie mayflies, Ephoron album (Say) and Ephemera simulans Walker. - Bull. Ohio. Biol. Surv. 1: 1-70.

Clement M., Posada D. \& Crandall K.A. 2000: TCS: a computer program to estimate gene genealogies. - Mol. Ecol. 9: $1657-1659$

Corbet P.S. 1966: Parthenogenesis in caddisflies (Trichoptera). - Can. J. Zool. 44: 981-982.

Cordero R.A., Lorenzo Carballa M.O., Utzeri C. \& Vieira V. 2005: Parthenogenetic Ischnura hastata (Say, 1839), widespread in the Azores Islands (Zygoptera: Coenagrionidae). Odonatologica 34: 1-9.
Corley L.S., Blankenship J.R., Moore A.J. \& Moore P.J. 1999: Developmental constraints on the mode of reproduction in the facultatively parthenogenetic cockroach Nauphoeta cinerea. - Evol. Dev. 1: 90-99.

Fochetti R. \& de Figueroa J.M.T. 2008: Global diversity of stoneflies (Plecoptera; Insecta) in freshwater. - Hydrobiologia 595: 365-377.

Funk D.H., SweEney B.W. \& JAcKson J.K. 2010: Why stream mayflies can reproduce without males but remain bisexual: a case of lost genetic variation. - J. N. Am. Benthol. Soc. 29: $1258-1266$.

HARPER P. 1973: Emergence, reproduction, and growth of setipalpian Plecoptera in southern Ontario. — Oikos 24: 94-107.

HufF B.L.J. \& McCAFFERTY W.P. 1974: Parthenogenesis and experimental reproductive biology in four species of the mayfly genus Stenonema. — Wasmann. J. Biol. 32: 247-254.

IsHIWATA S. 1996: A study of the genus Ephoron from Japan (Ephemeroptera, Polymitarcyidae). - Can. Entomol. 128: 551-572.

Kato H., Watanabe Y. \& Yoкота H. 1997: Preliminary note on artificial parthenogenesis in Stylurus oculatus (Odonata, Gomphidae). — New Entomol. 46: 16-19 [in Japanese].

Landolt P., Sartori M. \& Studemann D. 1997: Palingenia longicauda (Ephemeroptera, Palingeniidae): from mating to the larvulae stage. In Landolt P. \& Sartori M. (eds): Ephemeroptera - Plecoptera: Biology, Ecology, Systematics. Mauron + Tinguely \& Lachat, Fribourg, pp. 15-20.

Larkin M.A., Blackshields G., Brown N.P., Chenna R., McGettigan P.A., McWilliam H., Valentin F., Wallace I.M., Wilm A., Lopez R., Thompson J.D., Gibson T.J. \& Higgins D.G. 2007: Clustal W and Clustal X version 2.0. - Bioinformatics 23: 2947-2948.

Librado P. \& Rozas J. 2009: DnaSP v5: a software for comprehensive analysis of DNA polymorphism data. - Bioinformatics 25: 1451-1452.

Malicky H. \& PaULs S.U. 2012: Cross-breeding of Chaetopteryx morettii and related species, with molecular and eidonomical results (Trichoptera, Limnephilidae). - Ann. Limnol. Int. J. Lim. 48: 13-19.

Mingo T.M. 1978: Parthenogenesis in the mayfly Stenacron interpunctatum frontale (Burks) (Ephemeroptera: Heptageniidae). - Entomol. News 89: 46-50.

NAKAmuRa K. \& Endo T. 2001: Development of mayfly eggs in the river laid at different period. - Proc. Arthropod. Embryol. Soc. Jpn. 36: 17-19 [in Japanese with English captions].

Normark B.B. 2014: Modes of reproduction. In Shuker M.D. \& Simmons W.L. (eds): The Evolution of Insect Mating Systems. Oxford University Press, Oxford, pp. 1-19.

Pearcy M., Hardy O. \& Aron S. 2006: Thelytokous parthenogenesis and its consequences on inbreeding in an ant. - Heredity 96: $377-382$.

Russev B.K. 1987: Ecology, life history and distribution of Palingenia longicauda (Olivier) (Ephemeroptera). — Tijdschr. Entomol. 130: 109-127.

Salokannnel J., Rantala M.J. \& Wahlberg N. 2010: DNAbarcoding clarifies species definitions of Finnish Apatania (Trichoptera: Apataniidae). — Entomol. Fenn. 21: 1-11.

Sexiné K. \& Tojo K. 2010a: Potential for parthenogenesis of virgin females in a bisexual population of the geographically parthenogenetic mayfly Ephoron shigae (Insecta: Ephemeroptera, Polymitarcyidae). — Biol. J. Linn. Soc. 99: 326-334.

SEKINÉ K. \& ToJo K. 2010b: Automictic parthenogenesis of a geographically parthenogenetic mayfly, Ephoron shigae (Insecta: Ephemeroptera, Polymitarcyidae). — Biol. J. Linn. Soc. 99: 335-343. 
Seriné K., Hayashi F. \& Tojo K. 2013a: Phylogeography of the East Asian polymitarcyid mayfly genus Ephoron (Ephemeroptera: Polymitarcyidae): a comparative analysis of molecular and ecological characteristics. - Biol. J. Linn. Soc. 109: 181-202.

Seriné K., Kishimoto T., Kuranishi R.B. \& Tojo K. 2013b: Distribution research on a burrowing mayfly, Ephoron eophilum (Ephemeroptera: Polymitarcyidae), endemic to the Kanto Plain: findings from two river basins other than the Tone-gawa River Basin. - New Entomol. 62: 21-27.

Sekiné K., Furusana T. \& Hatakeyama M. 2015: The boule gene is essential for spermatogenesis of haploid insect male. - Dev. Biol. 399: 154-163.

Simon J.C., Delmotte F., Rispe C. \& Crease T. 2003: Phylogenetic relationships between parthenogens and their sexual relatives: the possible routes to parthenogenesis in animals. Biol. J. Linn. Soc. 79: 151-163.

Stephens M. \& Donnelly P. 2003: A comparison of Bayesian methods for haplotype reconstruction from population genotype data. - Am. J. Hum. Genet. 73: 1162-1169.

Stephens M., Smith N.J. \& Donnelly P. 2001: A new statistical method for haplotype reconstruction from population data. Am. J. Hum. Genet. 68: 978-989.

Suomalainen E., Saura A. \& LoKki J. 1987: Cytology and Evolution in Parthenogenesis. CRC Press, Boca Raton, FL, 216 pp.

Tamura K., Peterson D., Peterson N., Stecher G., Nei M. \& KuMAR S. 2011: MEGA5: Molecular evolutionary genetics analysis using maximum likelihood, evolutionary distance, and maximum parsimony methods. - Mol. Biol. Evol. 28: $2731-2739$
Templeton A.R. 1982: The prophecies of parthenogenesis. In Dingle H. \& Hegmann J.P. (eds): Evolution and Genetics of Life Histories. Springer, New York, pp. 75-101.

Thomson R.C., WANG I.J. \& Johnson J.R. 2010: Genome-enabled development of DNA markers for ecology, evolution and conservation. - Mol. Ecol. 19: 2184-2195.

Tojo K. \& MAchida R. 1997: Embryogenesis of the mayfly Ephemera japonica McLachlan (Insecta: Ephemeroptera, Ephemeridae), with special reference to abdominal formation. - J. Morphol. 234: 97-107.

Tojo K., Seriné K. \& Matsumoto A. 2006: Reproductive mode of the geographic parthenogenetic mayfly Ephoron shigae, with findings from some new localities (Insecta: Ephemeroptera, Polymitarcyidae). - Limnology 7: 31-39.

VAN DER KoOI C.J. \& SChwander T. 2014: On the fate of sexual traits under asexuality. - Biol. Rev. 89: 805-819.

WANG Q. \& WANG X. 2012: Comparison of methods for DNA extraction from a single chironomid for PCR analysis. - Pak. J. Zool. 44: 421-426.

Watanabe N.C. \& Ishiwata S. 1997: Geographic distribution of mayfly, Ephoron shigae in Japan, with evidence of geographic parthenogenesis (Insecta: Ephemeroptera: Polymitarcyidae). - Jpn. J. Limnol. 58: 15-25.

Watanabe Y., Yokota H., Kato H. \& Hatakeyama M. 1999: Artificial parthenogenesis in the dragonfly, Stylurus oculatus (Odonata). - Proc. Arthropod. Embryol. Soc. Jpn. 34: 31-32 [in Japanese with English captions].

Wigginton J.E., Cutler D.J. \& Abecasis G.R. 2005: A note on exact tests of Hardy-Weinberg equilibrium. - Am. J. Hum. Genet. 76: 887-893.

Received February 16, 2015; revised and accepted April 16, 2015 Prepublished online July 10, 2015 